\title{
KESANTUNAN BERBAHASA PADA PEMBELAJARAN BAHASA INGGRIS MAHASISWA UNIVERSITAS PUTERA BATAM
}

\author{
Afriana $^{1}$. Universitas Putera Batam. Batam-Kepri \\ afrianaupb@gmail.com \\ Robby Satria Mandala² ${ }^{2}$ Universitas Putera Batam. Batam-Kepri \\ robmandala@gmail.com
}

\begin{abstract}
The purpose of this study was to describe the attitude of the language towards the politeness of the language of the students of Putera Batam University. This study used a survey method. The sample in this study were 43 students of English Literature. Data obtained from observation sheets and questionnaires. Assessment is done using a Likert scale. The data analysis technique used descriptive statistics using technical regression analysis. The results of the study showed that language attitudes had a positive effect on student politeness. This finding recommends that the development of language attitudes will improve student language politeness. This study aims to analyze the language attitude of students of the English Literature study program at Putera University, then analyze the politeness of the students of the English Literature Study Program at the Putera Batam University. And the influence of language attitudes on the politeness of the language of students of English Literature Study Program, Putera Batam University.
\end{abstract}

Keywords: Politeness strategies, Learning

\section{PENDAHULUAN}

Kesantunan berbahasa adalah kaidah atau norma perilaku berbahasa secara patut yang ditetapkan dan disepakati bersama oleh suatu masyarakat untuk menjaga, memelihara hubungan sosial, psikologis antar penutur. Kesantunan berbahasa tercermin dalam tata cara berkomunikasi secara verbal atau tata cara berbahasa. Yule (1996:60) menyatakan bahwa, “... It is possible to treat politeness as a fixed concept, as in the idea of polite social behavior, or etiquette, within a culture...." Hal ini memungkinkan untuk memperlakukan kesantunan sebagai suatu konsep yang pasti, yang terdapat dalam gagasan perilaku sosial yang santun, atau etiket, dalam suatu kebudayaan.

Dari pernyataan diatas dapat dijelaskan bahwa kesantunan dapat diartikan sebagai suatu konsep tertentu, yang terdapat dalam perilaku sosial yang santun atau etiket dalam suatu kebudayaan. Kesantunan pada umumnya dipahami sebagai tindakan melakukan hal-hal yang dapat diterima oleh masyarakat dalam suatu komunitas. Menurut Kasper menyatakan kesantunan sebagai sebuah konsep pragmatik mengacu kepada cara tindak kebahasaan dilakukan, lebih khususnya, adalah cara fungsi relasional dalam tindak kebahasaan diungkapkan, (1998). 
Sebagai bidang baru dalam kajian kebahasaan, khususnya bahasa dalam penggunaan (language in use), kesantunan (politeness) dalam berbahasa seyogiyanya mendapatkan perhatian, baik oleh pakar atau linguis, maupun para pembelajar bahasa. Selain itu, penting juga bagi setiap orang untuk memahami kesantunan berbahasa ini, karena manusia yang kodratnya adalah "makhluk berbahasa" senantiasa melakukan komunikasi verbal yang sudah sepatutnya beretika.

Kesantunan dalam berbahasa mungkin merupakan horison baru dalam berbahasa, dan sampai saat ini belum dikaji dalam konstelasi linguistik; terkecuali dalam telaah pragmatik. Kesantunan dalam berbahasa, meskipun disebut sebagai horison baru, namun sudah mendapatkan perhatian oleh banyak linguis dan pragmatisis. Misalnya Aziz (2000) yang meneliti bagaimana cara masyarakat Indonesia melakukan penolakan dengan melalui ucapan, yang menurutnya mengandung nilainilai kesantunan tersendiri. Hal ini sekaligus menunjukkan bahwa terdapat bidang baru dalam kajian kebahasaan, bukan hanya dari aspek tata bahasa, bukan pula dari aspek psikososial, namun juga dari aspek etika.

Meskipun dalam ilmu pragmatik kesantunan berbahasa baru mulai mendapatkan perhatian, konsep etika berbahasa ini sudah bisa dibilang lama bersemayam dalam komunikasi verbal masyarakat manapun. Kesantunan berbahasa, secara tradisional, diatur oleh norma-norma dan moralitas masyarakat, yang diinternalisasikan dalam konteks budaya dan kearifan lokal. Tata krama berbahasa antara yang muda dan yang tua, sudah lama hidup dalam komunikasi verbal, yang justru mulai sirna mengikuti arus negatif westernisasi, yang membawa ideologi liberal.

Konsep kesantunan dalam berbahasa tradisional itu sudah saatnya "dibaca" kembali secara teoretis, agar terjadi penyegaran ideologi mengenai bagaimana seharusnya bahasa itu digunakan, agar santun. Tulisan ini akan memberikan pandangan teoretis mengenai ihwal kesantunan berbahasa, yang mana dapat dijadikan acuan untuk kembali melakukan refleksi atas penggunaan bahasa sehari-hari. Refleksi untuk melihat nilai kesantunan dalam penggunaan bahasa sehari-hari terbilang penting, dimana bahasa bukan hanya sebagai instrumen komunikasi, melainkan juga ajang realisasi diri yang santun dan beretika.

Bersikap atau berbahasa santun dan beretika juga bersifat relatif, tergantung pada jarak sosial penutur dan mitra tutur. Selain itu, makna kesantunan dan kesopanan juga dipahami sama secara umum; sementara itu, kedua hal tersebut sebenarnya berbeda. Istilah sopan merujuk pada susunan gramatikal tuturan berbasis kesadaran bahwa setiap orang berhak untuk dilayani dengan hormat, sementara santun itu berarti kesadaran mengenai jarak sosial Thomas (1995).

Menurut Brown dan Levinson (1987), yang mana terinspirasi oleh Goffman (1967), bahwasanya bersikap santun itu adalah bersikap peduli pada "wajah" atau "muka," baik milik penutur, maupun milik mitra tutur. "Wajah," dalam hal, ini bukan dalam arti rupa fisik, namun "wajah” dalam artian public image, atau mungkin padanan 
kata yang tepat adalah "harga diri" dalam pandangan masyarakat.

Konsep wajah ini berakar dari konsep tradisional di Cina, yang dikembangkan oleh Konfusius terkait dengan nilai-nilai kemanusiaan (Aziz, 2008). Pada wajah, dalam tradisi Cina, melekat atribut sosial yang merupakan harga diri, sebuah penghargaan yang diberikan oleh masyarakat, atau dimiliki secara individu. Wajah, merupakan "pinjaman masyarakat," sebagaimana sebuah gelar akademik yang diberikan oleh sebuah perguruan tinggi, yang kapan saja bisa ditarik oleh yang memberi. Oleh karena itu, si pemilik wajah itu haruslah berhati-hati dalam berprilaku, termasuk dalam berbahasa.

Jika Goffman (1967) menyebutkan bahwa wajah adalah atribut sosial, maka Brown dan Levinson (1987) menyebutkan bahwa wajah merupakan atribut pribadi yang dimiliki oleh setiap insan dan bersifat universal. Dalam teori ini, wajah kemudian dipilah menjadi dua jenis: wajah dengan keinginan positif (positive face), dan wajah dengan keinginan negatif (negative face). Wajah positif terkait dengan nilai solidaritas, ketakformalan, pengakuan, dan kesekoncoan. Sementara itu, wajah negatif bermuara pada keinginan seseorang untuk tetap mandiri, bebas dari gangguan pihak luar, dan adanya penghormatan pihak luar terhadap kemandiriannya itu (Aziz, 2008:2). Melihat bahwa wajah memiliki nilai seperti yang telah disebutkan, maka nilai-nilai itu patut untuk dijaga, dan salah satu caranya adalah melalui pola berbahasa yang santun, yang tidak merusak nilai-nilai wajah itu.

Kesantunan itu sendiri memiliki makna yang berbeda dengan kesopanan. Kata sopan memiliki arti menunjukkan rasa hormat pada mitra tutur, sedangkan kata santun memiliki arti berbahasa (atau berprilaku) dengan berdasarkan pada jarak sosial antara penutur dan mitra tutur. Konsep wajah di atas benar-benar berkaitan dengan persoalan kesantunan dan bukan kesopanan. Rasa hormat yang ditunjukkan melalui berbahasa mungkin berakibat santun, artinya, sopan berbahasa akan memelihara wajah jika penutur dan mitra tutur memiliki jarak sosial yang jauh (misalnya antara dosen dan mahasiswa, atau anak dan ayah). Meskipun demikian, bersikap santun dalam berbahasa seringkali tidak berakibat sopan, terlebih lagi jika penutur dan mitra tutur tidak memiliki jarak sosial yang jauh (teman sekerja, konco, pacar, dan sebagainya).

Menurut Suyono (1990) aturanaturan dalam prinsip kesantunan memiliki aturan berkaitan dengan kebijaksanaan yang berkaitan dengan kerugian dan keuntungan dalam situasi tutur, yaitu (1) perkecil kerugian pada orang lain, (2) perbesar keuntungan pada orang lain, aturan kedermawanan terikat pada aturan-aturan, yaitu (1) kurangi keuntungan bagi diri sendiri, (2) tambahilah pengorbanan pada diri sendiri. Selanjutnya aturan penghargaan menyarankan, (1) kurangi cacian pada orang lain, (2) tambahilah pujian pada orang lain. Aturan kesederhanaan menyarankan, (1) kurangi pujian pada diri sendiri, (2) tambahilah cacian pada diri sendiri. Aturan pemufakatan menyarankan, (1) kurangi ketidaksesuaian antara diri sendiri dengan orang lain, (2) tingkatkan penyesuaian diri sendiri dengan orang lain. Aturan kesimpatian menyarankan, (1) kurangi antipati antara diri sendiri dan orang lain, dan 
(2) perbesarlah simpati antara diri sendiri dan orang lain.

Aturan-aturan di atas merupakan perwujudan dalam peristiwa tutur yang dapat terjadi secara simultan yang pada dasarnya sebagai pelengkap prinsipprinsip kerjasama.

Dalam kondisi tertentu prinsip kerjasama lebih dominan daripada prinsip kesantunan, sementara itu pada kondisi yang lain kemungkinan akan terjadi sebaliknya prinsip kesantunan lebih dominan daripada prinsip kerjasama.

Selain itu, kesantunan dalam kajian pragmatik diuraikan oleh beberapa ahli. Diantaranya adalah Leech, Robin Lakoff, Bowl dan Levinson. Prinsip kesopanan memiliki beberapa maksim, yaitu maksim kebijaksanaan (tact maxim), maksim kemurahan (generosity maxim, maksim penerimaan (approbation maxim), maksim kerendahhatian (modesty maxim), maksim kecocokan (agreement maxim), dan maksim kesimpatian (sympathy maxim). Menurut Dewa Putu Wijana (1996) Prinsip kesopanan ini berhubungan dengan dua peserta percakapan, yakni diri sendiri (self) dan orang lain (other). Diri sendiri adalah penutur, dan orang lain adalah lawan tutur (Maksim merupakan kaidah kebahasaan di dalam interaksi lingual* kaidah+kaidah yangmengatur tindakannya, penggunaan bahasanya, dan interpretasi+interpretasinya terhadaptindakan dan ucapan lawan tuturnya. Selain itu maksim juga disebut sebagai bentuk pragmatik berdasarkan prinsip kerja sama dan prinsip kesopanan. Maksimmaksim tersebut menganjurkan agar kita mengungkapkan keyakinan-keyakinan dengan sopan dan menghindari ujaran yang tidak sopan.
Sementara itu, Culpeper membagun strategi ketidaksantunan sebagai strategi yang berlawanan dengan strategi kesopanan Brown dan Levinson (1987), yaitu strategi (1) bald on record impoliteness yaitu strategi ketidaksantunan yang sengaja dilakukan dengan terus terang tanpa mempertimbangkan wajah mitra tutur, (2) positive impoliteness, adalah strategi yang sengaja untuk mengancam wajah positive mitra tutur, (3) negative impoliteness, adalah strategi yang sengaja untuk mengancam wajah negative mitra tutur, (4) sarcasm or mock politeness, strategi ini dilakukan dengan menggunakan strategi kesopanan yang sengaja dibuat-buat (5) withhold politeness.

a. Bald on record impoliteness (ketidaksantunan Bald on Record) Dalam strategi ini ketidaksantunan terjadi karena penutur dengan sengaja tidak ingin bekerjasama dengan mitra tutur atau penutur tidak ingin menjaga hubungan baik dengan mitra tutur. Faktor kesengajaan untuk tidak ingin menjaga hubungan baik dengan mitra tutur merupakan hal yang membedakannya dengan kesantunan Bald on record milik Brown dan Levinson (1987). Menurut Brown dan Levisnon, kesantunan Bald on record dapat dilakukan dalam situasi yang mendesak atau genting sehingga penutur tidak perlu menggunakan strategi untuk menjaga muka mitra tutur.

b. Positive impoliteness (ketidaksantunan positif) Strategi ini digunakan pembicara untuk merusak muka positif mitra tutur. Muka positif yang dimaksud adalah keinginan setiap individu untuk dihormati, dihargai, diinginkan dan dibutuhkan oleh 
orang lain. Berikut adalah beberapa substrateginya:

(1) Mengabaikan orang lain - yaitu dengan cara penutur tidak menghiraukan lawan bicara ketika mereka berada di setting yang sama. Tidak menghiraukan juga dapat berupa tindakan tidak memberi kesempatan berbicara, tidak mau menghormati pendapat lawan bicara dan sebagainya.(2) Mengucilkan orang lain. Strategi ini hampir sama dengan strategi No 1, namun dalam strategi ini penutur dengan sengaja membatasi diri agar mitra tutur tidak terlibat berkomunikasi dengannya.(3) Menarik diri atau memisahkan diri dari mitra tutur yang tidak mempunyai pendapat yang sama dengan dirinya atau kelompoknya, misalnya membantah, tidak mau mengakui pendapat orang lain.(4) Menunjukkan atau mengekspresikan rasa ketidaktertarikan, ketidakperdulian, dan ketidak simpatian.(5) Menggunakan sebutan atau julukan yang tidak pantas kepada mitra tutur atau memanggil mitra tutur dengan nama atau julukan yang bersifat menghina. Menggunakan jargon atau slang agar orang lain di luar kelompoknya tidak dapat memahami pembicaraannya. (7) Membuat orang lain merasa tidak nyaman dengan bahasa yang digunakannya. (8) Menggunakan kata-kata tabu, sumpahserapah atau bahasa yang kasar.

c. Negative impoliteness (ketidaksantunan negatif) Tidak seperti kesantunan negatif yang berfungsi untuk menjaga muka negatif mitra bicara yaitu menjaga agar mereka tidak diganggu, ketidaksantunan negatif bertujuan merusak muka negatif, yaitu mengganggu keinginan untuk tidak diganggu. Sebagi contoh adalah sebagai berikut:
(1) Menakut-nakuti-menanamkan keyakinan bahwa hal-hal buruk akan terjadi pada mitra tutur. (2) Mencemooh, mengkritik atau mengejek - dengan strategi ini pembicara menunjukkan superioritasnya. Termasuk juga mencela, menyalahkan, menunjukan kelemahan orang lain.(3) Menghina orang lain dan memperlakukan mereka dengan semena-mena.(4) Meremehkan atau merendahkan orang lain.(5) Melanggar ruang pribadi (infringement of personal space) dalam arti harfiah maupun metaforis, misalnya menguping pembicaraan orang lain, membaca arsip/dokumen orang lain yang bukan menjadi haknya, memaksa mitra tutur berbicara tentang sesuatu yang intim atau pribadi yang tidak semestinya.(6) Secara eksplisit mengaitkan mitra tutur dengan halhal negatif.(7) Membuat orang lain seolaholah berhutang budi kepada pembicara.

d. Mock impoliteness - dalam strategi ini pembicara melakukan ketidaksantunan semu. Ketidaksantunan jenis ini terjadi ketika pembicara menggunakan kesantunan akan tetapi mereka menggunakan kesantunan tersebut untuk tujuan lain, misalnya untuk mengolok-olok dan sebagianya.

Penelitian ini diarahkan kepada fungsi tuturan yang mencakup (1) Menyatakan dengan indikator memberi pernyataan, memberikan informasi, menyatakan janji, memberi keputusan, memberi penjelasan, (2) Bertanya dengan indikator bertanya, meminta keterangan, meminta pendapat, meminta kesungguhan, meminta izin, (3) Memerintah dengan indikator menyuruh, melarang, menyetujui, menolak, (4) Mengkritik dengan indikator mengkritik, menilai, Searle (, 1975). 
Anderson (1990) menyatakan sikap bahasa adalah tata keyakinan atau kognisi yang relatif berjangka panjang, sebagian mengenai bahasa, mengenai objek bahasa, yang memberikan kecenderungan seseorang untuk bereaksi dengan cara tertentu yang disenanginya. Namun sikap tersebut dapat berupa sikap positif dan negatif, maka sikap terhadap bahasa pun demikian. Garvin and Mathiot merumuskan tiga ciri sikap bahasa yaitu: (1) Kesetiaan Bahasa (Language Loyalty), (2) Kebanggaan Bahasa (Language Pride), (3) Kesadaran adanya normabahasa (Awareness Of The Norm), (Hudson, 1980).

Berdasarkan penjelasan diatas, peneliti imenganalisa tentang Sikap bahasa mahasiswa Program Studi Sastra Inggris Universitas Putera Batam, Kesantunan berbahasa mahasiswa Program Studi Sastra Inggris Universitas Putera Batam. Dan Pengaruh sikap bahasa terhadap kesantunan berbahasa mahasiswa Prodi Sastra Inggris Universitas Putera Batam.

\section{METODE PENELITIAN}

Penelitian ini adalah kuantitatif asosiatif. Penelitian ini dilakukan di Universitas Putera Batam. Populasi penelitian adalah mahasiswa Sastra Inggris sebanyak 300 orang. Sedangkan besarnya sampel yang ditetapkan dengan menggunakan cluster random sampling berjumlah 43 orang. Pengumpulan data menggunakan kuesioner, observasi, dan tes yang terlebih dahulu dilakukan pengujian validitas dengan menggunakan rumus korelasi Pearson Produc Moment dan Judgement validity, perhitungan reliabilitas menggunakan teknik Alpha Cronbach. Data yang diperoleh dari hasil penelitian dianalisis dengan analisis deskriptif dan inferensial. Analisis deskriptif digunakan untuk memperoleh gambaran karakteristik variabel penelitian. Sedangkan analisis inferensial digunakan untuk menguji hipotesis. Sebelum dilakukan analisis terlebih dahulu dilakukan uji normalitas dan linieritas. Untuk menguji hipotesis digunakan teknik analisis data dengan model regresi.

\section{HASIL DAN PEMBAHASAN}

Dari data yang telah ditemukan dan dianalisa, hasil dari penelitian ini menunjukkan bahwa deskripsi data dalam penelitian ini disajikan sebagai informasi tentang sebaran/distribusi dan pemusatan data hasil penelitian yang berupa skor minimum, skor maksimum, mean (rata-rata), modus (skor yang memiliki frekuensi terbanyak), median, simpangan baku, varian, distribusi frekuensi dan histogram. Dalam penelitian ini terdapat variabel endogen/terikat yaitu Kesantunan Berbahasa (Y), variabel eksogen atau variebel bebas yaitu Sikap Bahasa (X). Setelah diujicobakan, maka langkah selanjutnya adalah melakukan pengumpulan data yang diawali dengan mencari mean,dan standard deviasi. Berikut hasil penjaringan data melalui instrumen penelitian yang telah diuji coba. Hasil analisis deskriptif selengkapnya disajikan dalam tabel berikut ini:

Tabel 1. Rekapitulasi Perhitungan Statistik Deskriptif

\begin{tabular}{|l|l|l|l|l|l|}
\hline \multirow{2}{*}{ Variabel } & \multirow{2}{*}{$\mathrm{N}$} & \multicolumn{5}{|c|}{ Statistik Deskriptif } \\
\cline { 4 - 6 } & & MIN & MAX & MEAN & SD \\
\hline $\mathrm{X}$ & 43 & 50 & 74 & 62,79 & 5,926 \\
\hline $\mathrm{Y}$ & 43 & 140 & 178 & 159,40 & 9,386 \\
\hline
\end{tabular}


Berdasarkan tabel di atas, selanjutnya akan diuraikan deskripsi data untuk masing-masing variabel. Kesantunan Berbahasa (Y) Instrumen kesantunan berbahasa (Y) terdiri dari 16 item pernyataan, secara teoritik rentang skor yang diperoleh dari sampel adalah 16 - 80. Hasil pengumpulan data menunjukkan skor terendah 50 dan skor tertinggi 74. Dengan nilai skor rentang sebesar 24. Nilai rata-rata kesantunan berbahasa sebesar 62,79 dengan standar deviasi 5,926. Hal ini menunjukkan bahwa tingkat kesantunan berbahasa mahasiswa termasuk ke dalam kategori Santun. Distribusi skor kesantunan berbahasa secara rinci disajikan dalam tabel berikut ini:

\begin{tabular}{cccc}
\multicolumn{5}{c}{ Tabel 2. Distribusi Skor Kesantunan Berbahasa } \\
\hline $\begin{array}{c}\text { Kelas } \\
\text { Interval }\end{array}$ & Kelas interval & $\begin{array}{c}\text { Frekuensi } \\
\text { Absolut }\end{array}$ & Frekuensi Kumulatif \\
\hline 1 & $50-53$ & 2 & 2 \\
\hline 2 & $54-57$ & 5 & 7 \\
\hline 3 & $58-61$ & 9 & 16 \\
\hline 4 & $62-65$ & 12 & 28 \\
\hline 5 & $66-69$ & 8 & 36 \\
\hline 6 & $70-73$ & 6 & 42 \\
\hline 7 & $74-77$ & 1 & 43 \\
\hline \multicolumn{7}{c}{ Jumlah } & 43 & \\
\hline
\end{tabular}

Berdasarkan tabel 2 di atas dapat dilihat bahwa skor kesantunan berbahasa yang memiliki frekuensi yang paling banyak adalah 12 yang berada pada kelas interval 6265. Selanjutnya untuk menunjukkan bentuk visual distribusi frekuensi skor kesantunan berbahasa disajikan dalam histogram berikut:

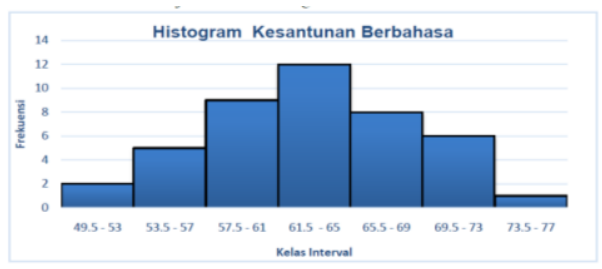

Sikap Bahasa (X)

Instrumen sikap bahasa (X2) terdiri atas 50 item pernyataan, secara teoretik rentang skor yang diperoleh dari sampel adalah 50 - 200. Hasil pengumpulan data menunjukkan skor terendah 140 dan skor tertinggi 178. Dengan nilai rentang skor sebesar 38. Nilai rata-rata sikap bahasa sebesar 159,40 dengan standar deviasi 9,386.

Distribusi skor sikap bahasa secara rinci disajikan dalam tabel berikut ini:

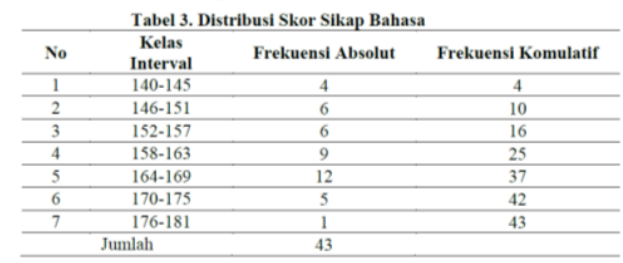

Berdasarkan tabel 3 di atas dapat dilihat bahwa skor sikap bahasa yang memiliki frekuensi yang paling banyak adalah 12 yang berada pada kelas interval 164-169. Selanjutnya untuk menunjukkan bentuk visual distribusi frekuensi skor sikap bahasa disajikan dalam histogram berikut:

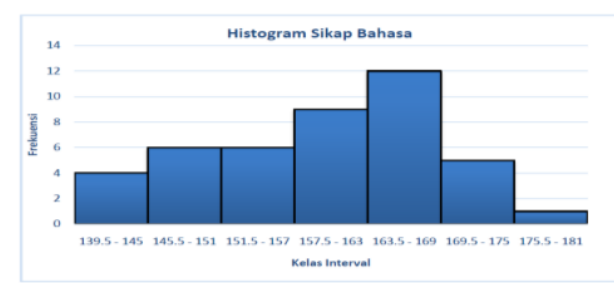

Pengujian Hipotesis

Untuk membuktikan bahwa Sikap Bahasa berpengaruh positif terhadap Kesantunan Berbahasa hipotesis statistik yang diuji adalah : Ho : $\beta$ yx $\leq 0$

Ha : $\beta$ yx $>0$

Berdasarkan hasil analisis data dengan menggunakan aplikasi SPSS

diperoleh koefisien $\mathrm{X}$ ke $\mathrm{Y}$ (pyx) sebesar 0,320 dengan thitung $=2,492$ dan ttabel $(\alpha=$ $0,05,42)=2,020$. Dengan demikian nilai thitung $(2,492)>$ ttabel $(2,020)$ yang berarti Ho ditolak dan $\mathrm{Ha}$ diterima. Artinya koefisien jalur (pyx) signifikan. Temuan ini diinterpretasikan bahwa Sikap Bahasa (X) berpengaruh langsung positif terhadap Kesantunan Berbahasa (Y), artinya perbaikan 
Sikap Bahasa akan mengakibatkan peningkatan Kesantunan Berbahasa. Dari Tabel Coefficientsa diperoleh standardized Coefficient untuk variabel X (sikap bahasa) diperoleh standardized Coefficient $=0,320$ dan nilai signya (peluang $\mathrm{p}$ ) $=0,017$. Nilai peluang variabel penelitian di atas kurang dari 0,05 ( $\operatorname{sig}<\alpha=0,05)$, maka hasilnya dinyatakan signifikan. Diperoleh koefisien py2 $=0,320$. Disimpulkan bahwa terdapat pengaruh variabel $\mathrm{X}$ terhadap $\mathrm{Y}$ adalah sebesar 32,0\%, Persamaan regresinya : $Y=$ 0,269X1 + 0,202 X2 + 0,299 X3 - 17,257.

Pengaruh Sikap Bahasa (X) terhadap Kesantunan Berbahasa (Y)

Dalam penelitian ini ditemukan bahwa Sikap bahasa berpengaruh terhadap Kesantunan Berbahasa. Keeratan hubungan antara X dengan $\mathrm{Y}$ dipertegas dengan hasil pengujian hipotesis yang diajukan dalam penelitian ini yaitu terdapat pengaruh positif sikap bahasa (X) terhadap kesantunan berbahasa (Y) mahasiswa. Dengan demikian peningkatan sikap bahasa akan mengakibatkan terjadinya peningkatan kesantunan berbahasa mahasiswa.

Temuan penelitian yang menyatakan bahwa terdapat pengaruh positif sikap bahasa terhadap kesantunan berbahasa secara empirik mendukung dan memperkuat beberapa teori atau pendapat para pakar tentang pengaruh sikap bahasa terhadap kesantunan berbahasa sebagaimana berikut ini.

Suatu bahasa merupakan pelibatan diri dalam bentuk tingkah laku yang taat kaidah. Dengan perkataan lain perilaku berbahasa seseorang juga akan terlihat pada kesadaran akan norma bahasa, penggunaan bahasa yang cermat, tertib, dan mengikuti kaidah yang berlaku (Searle). Sikap bahasa pada hakikatnya adalah reaksi atau pandangan seseorang terhadap suatu bahasa yang ditunjukkan dalam perilaku penggunaan bahasa. Sikap bahasa berkenaan dengan aspek kesetiaan, kebanggaan terhadap bahasa, dan

kesadaran akan norma bahasa. Bila seseorang berbahasa mempertimbangkan ketiga aspek tersebut artinya seseorang bersikap positif terhadap bahasanya, demikian sebaliknya. Sikap positif yaitu sikap antusiasme terhadap penggunaan bahasa yang digunakan oleh masyarakat dimana dia berada. Sebaliknya jika ciriciri itu sudah menghilang atau melemah dari diri seseorang atau dari diri sekelompok anggota masyarakat, maka berarti seseorang telah bersikap negatif terhadap bahasanya.

Sikap positif berhubungan dengan sikap atau tingkah laku yang tidak bertentangan dengan kaidah atau norma yang berlaku. Sikap positif terhadap bahasa membuat seseorang senantiasa menggunakan bahasa yang benar dalam situasi yang tepat. Penggunaan bahasa yang benar artinya penggunaan bahasa yang sesuai dengan kaidah berbahasa Indonesia dan sesuai dengan situasi kebahasaan. Sikap positif juga ditunjukkan dengan sikap setia memakai bahasa sendiri tanpa dicampur dengan bahasa asing. Sikap bahasa yang positif hanya akan tercermin apabila si pemakai mempunyai rasa 'setia' untuk memelihara dan mempertahankan bahasanya sebagai sarana untuk berkomunikasi. Sikap positif terdapat pada seseorang yang mempunyai rasa bangga terhadap bahasanya sebagai penanda jati diri.

Geertz menjelaskan bahwa bahasa santun adalah bahasa yang dipergunakan oleh 
masyarakat dengan memperhatikan adanya hubungan sosial antar pembicara dan penyimak dan bentuk status serta keakraban. Rasa setia, bangga, dan kesadaran akan norma bahasa Indonesia membuat seseorang memilih menggunakan bahasa Indonesia sesuai dengan kaidah atau taat azas pada bahasa Indonesia. Moeliono menyatakan bahasa santun berkaitan dengan tata bahasa, dan pilihan kata. Pilihan kata yang merupakan salah satu aspek sikap bahasa yaitu taat akan norma atau kaidah bahasa. Dari beberapa pendapat ahli di atas dikemukakan sikap bahasa diduga berpengaruh positif terhadap kesantunan berbahasa.

Temuan penelitian yang menyatakan terdapat pengaruh positif sikap bahasa terhadap kesantunan berbahasa mahasiswa sesuai dengan teori atau pendapat para ahli yang diuraikan di atas. Hal ini berarti baik secara teoretik maupun emprik menunjukkan peningkatan sikap bahasa akan mengakibatkan peningkatan kesantunan berbahasa

mahasiswa.

\section{KESIMPULAN}

Berdasarkan hasil penelitian dan pembahasan, maka dapat disimpulkan bahwa:

1. Sikap bahasa berpengaruh positif terhadap kesantunan berbahasa mahasiswa Universitas Putera Batam.

2. Sikap bahasa mahasiswa Sastra Inggris termasuk ke dalam kategori Positif.

3. Kesantunan berbahasa Mahasiswa termasuk ke dalam kategori Santun.

4. Terdapat pengaruh positif sikap bahasa terhadap kesantunan berbahasa mahasiswa Universitas Putera Batam.
5. Pengaruh positif menunjukkan bahwa peningkatan sikap bahasa, akan mengakibatkan peningkatan pada kesantunan berbahasa mahasiswa Universitas Putera Batam.

\section{DAFTAR PUSTAKA}

Anderson, John R. 1990. Cognitive Psychology and Its implicatio, 3rd.edition. New York: W. Hfreeman and Company.

Culpeper, Jonathan. 1996. Toward an anatomy of impoliteness. Journal of Pragmatics 25, 349-367.
---------. $2010 . \quad$ Conventionalized impoliteness formulae. Journal of Pragmatics 42, 3232-3245.

De Saussure, Ferdinand. 2009. Pengantar Linguistik Umum, terjemahan Rahayu

S. Hidayat. Yogyakarta: Gajah Mada University Press.

Deutschman, Mats. 2003. Apologising in British English. Umea Universitet.

Hudson, RA. 1980. Sociolinguistics. Cambridge: Cambridge University Press.

Hymes, Dell. 1980. Toward Ethnographies of Communication: The Analysis of communicative Events. In: Language and Social Context.Editor: Giglioli, Pier paolo. Essex : Penguin Books.

Kasper, G. (1998). Interlanguage pragmatics. In Learning Foreign and Second Languages:Perspectives in Research and Scholarship [Teaching Languages,Literatures, and Cultures 1], H.Byrnes (ed), 183-208. NY: Modern Language Association 
Kasper, G. 1998. "Politeness": Concise Encyclopeia of Pragmatics, ed. Jacob L. Mey.Oxford: Elsevier Science.

Searle, John R. 1999. Speech Act: An Essay in the Philosophy. Cambridge:

Cambridge University Press, 1999.

Yule, George. 1996. Pragmatics. Oxford: University Press.

Wijaya, I Dewa Putu. (1996), Dasar-dasar Pragmatik. Yogyakarta: Penerbit Andi. 